\title{
Diurnal warm-layer events in the western Mediterranean and European shelf seas
}

\author{
C. J. Merchant, ${ }^{1}$ M. J. Filipiak, ${ }^{1}$ P. Le Borgne, ${ }^{2}$ H. Roquet, ${ }^{2}$ E. Autret, ${ }^{3}$ \\ J.-F. Piollé, ${ }^{3}$ and S. Lavender ${ }^{4}$ \\ Received 20 December 2007; revised 8 January 2008; accepted 14 January 2008; published 16 February 2008.
}

[1] We characterize near-surface ocean diurnal warm-layer events, using satellite observations and fields from numerical weather forecasting. The study covers April to September, 2006 , over the area $11^{\circ} \mathrm{W}$ to $17^{\circ} \mathrm{E}$ and $35^{\circ} \mathrm{N}$ to $57^{\circ} \mathrm{N}$, with $0.1^{\circ}$ cells. We use hourly satellite SSTs from which peak amplitudes of diurnal cycles in SST (dSSTs) can be estimated with error $\sim 0.3 \mathrm{~K}$. The diurnal excursions of SST observed are spatially and temporally coherent. The largest dSSTs exceed $6 \mathrm{~K}$, affect $0.01 \%$ of the surface, and are seen in the Mediterranean, North and Irish Seas. There is an anti-correlation between the magnitude and the horizontal length scale of dSST events. Events wherein dSST exceeds $4 \mathrm{~K}$ have length scales of $\leq 40 \mathrm{~km}$. From the frequency distribution of different measures of windspeed minima, we infer that extreme dSST maxima arise where conditions of low wind speed are sustained from early morning to mid afternoon. Citation: Merchant, C. J., M. J. Filipiak, P. Le Borgne, H. Roquet, E. Autret, J.-F. Piollé, and S. Lavender (2008), Diurnal warm-layer events in the western Mediterranean and European shelf seas, Geophys. Res. Lett., 35, L04601, doi:10.1029/2007GL033071.

\section{Diurnal Cycles in Sea Surface Temperature}

[2] A diurnal cycle of radiometric sea surface temperature (SST) arises from formation and destruction of nearsurface "warm layers" [Fairall et al., 1996; Kawai and Wada, 2007]. The amplitude of this cycle is commonly reported as up to $\sim 4 \mathrm{~K}$ [e.g., Stramma et al., 1986], although larger events have been claimed [Flament et al., 1994]. Solar heating is greatest near the ocean surface, favouring near-surface thermal stratification, while winddriven mixing erodes diurnal stratification. Other factors influencing diurnal stratification are freshwater flux (mainly in the tropics) [e.g., Webster et al., 1996] and water opacity [e.g., Ramp et al., 1991].

[3] The terminology adopted here for diurnal variability is from Donlon et al. [2007]. The foundation temperature is the SST before diurnal heating commences at a depth below significant diurnal stratification (e.g., $\sim 10 \mathrm{~m}$ ) - it is the temperature on which any diurnal warm layer builds. The instantaneous infrared cooling and the latent and sensible heat fluxes are all controlled by the skin SST (essentially

\footnotetext{
${ }^{1}$ School of GeoSciences, University of Edinburgh, Edinburgh, UK.

${ }^{2}$ Centre de Météorologie Spatiale, Météo-France, Lannion, France.

${ }^{3}$ Ifremer, Plouzane, France.

${ }^{4}$ School of Earth, Ocean and Environmental Sciences, University of Plymouth, Plymouth, UK.
}

Copyright 2008 by the American Geophysical Union. 0094-8276/08/2007GL033071\$05.00 equal to the radiometric SST observed at infra-red wavelengths). The modification of instantaneous air-sea heat flux from diurnal warm-layer formation can be $50 \mathrm{~W} \mathrm{~m}^{-2}$ [Ward, 2006]. Climate records from satellite display nonclimatic trends [Kennedy et al., 2007] from drift in the overpass time relative to the diurnal SST cycle. Sampling different phases of the diurnal cycle contributes to bias between SST products. Diurnal SST variation also modulates air-sea fluxes of gases [e.g., McNeil and Merlivat, 1996].

[4] The dependence of diurnal warming on wind speed was characterized by Murray et al. [2000] for satellite observations at $\sim 1030 \mathrm{~h}$ local time in the tropical Pacific. SST observations from polar-orbiting [Stuart-Menteth et al., 2003] and asynchronous [Gentemann et al., 2003] satellites have been used to characterize of diurnal warming at other times of day. In none of these studies have full diurnal cycles been resolved in time.

[5] Here, we characterize the magnitude and the spatial scales of diurnal variability in the western Mediterranean and European Seas using hourly satellite SSTs. The wind in this region is heavily influenced by land-sea contrasts and orographic effects. Clear skies and diurnal warming events occur frequently in much of this region (M. J. Filipiak et al., manuscript in preparation, 2008).

\section{Data}

[6] We use $0.1^{\circ}$ Spinning Enhanced Visible and InfraRed Imager (SEVIRI) SSTs, obtained from hourly imagery, developed in the framework of the EUMETSAT Ocean and Sea Ice Satellite Application Facility (OSI-SAF) [Le Borgne et al., 2006]. The same SST retrieval algorithm is used day and night, for consistent observation of the diurnal cycle. The difference between these SSTs and matched drifting buoys (between July 2004 and July 2005) has mean and standard deviation of $\sim 0.01 \pm 0.49 \mathrm{~K}$. This standard deviation includes both drifter errors and spatially correlated retrieval errors. We estimate random radiometric noise from differences in SEVIRI SSTs between consecutive hours between midnight and dawn (to minimize diurnal trends), excluding aerosol (using an index of Saharan dust, see below) and cloud-masked pixels. We obtain standard deviation $0.11 \mathrm{~K}$. The full cycle of SST is available from SEVIRI, except under cloud cover. A further collated SEVIRI product is the "Saharan dust index" (SDI) [Merchant et al., 2006]. SDI is a dimensionless index based on infra-red wavelengths (and therefore available at night). It is scaled to be roughly comparable to visible aerosol optical depth around $550 \mathrm{~nm}$ when dust is present, and typically takes values between 0 and 2 . 

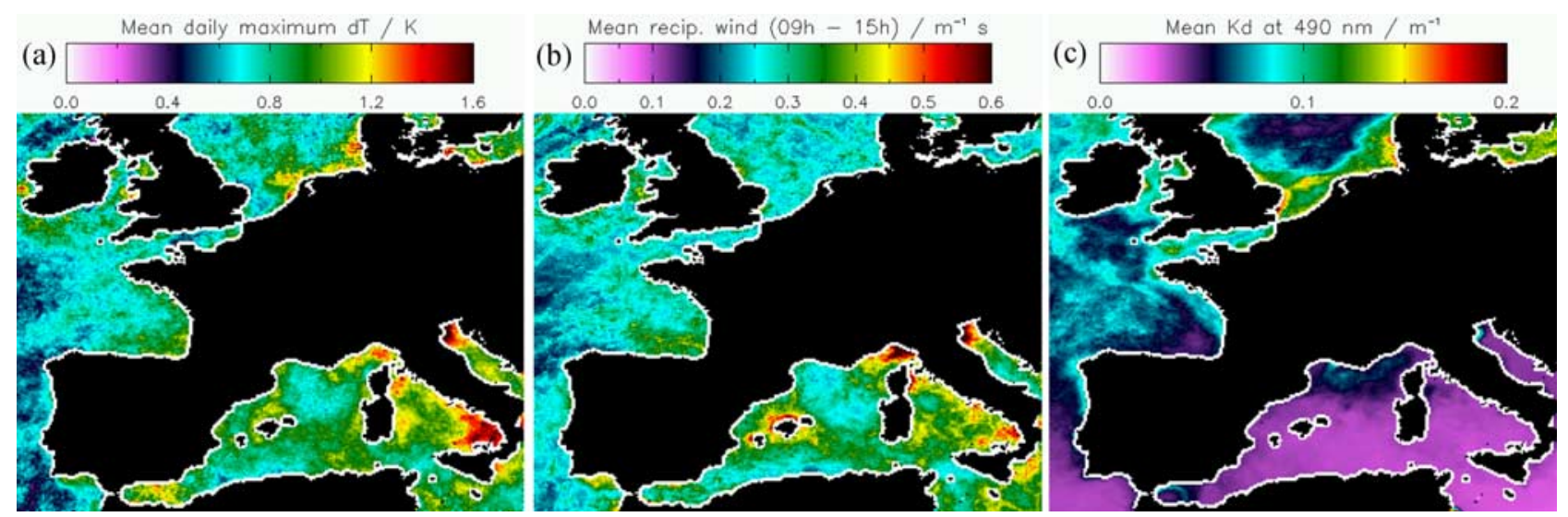

Figure 1. (a) Mean of the daily maximum of the diurnal cycle in sea surface temperature over the study area and period. (b) Aladin $0.1^{\circ}$ resolution wind field, represented by the mean of the reciprocal of the wind speed between 0900 and $1500 \mathrm{~h}$ UTC. (c) Mean of the diffuse attenuation coefficient at $490 \mathrm{~nm}$.

[7] We obtain hourly forecast fields from the ALADIN numerical weather prediction (NWP) model [Pailleux et al., 2005]. This runs at $0.1^{\circ}$ resolution, spanning $11^{\circ} \mathrm{W}$ to $17^{\circ} \mathrm{E}$ and $35^{\circ} \mathrm{N}$ to $57^{\circ} \mathrm{N}$. This area defines our domain, in which there are $225790.1^{\circ}$ cells that are classed as sea. The ALADIN fields are: zonal and meridional $10 \mathrm{~m}$ wind speed, net surface solar irradiance, net surface infrared irradiance, latent and sensible heat fluxes. A daily field of optical properties was obtained from the European Space Agency project "GlobColour", namely, the diffuse attenuation coefficient at $490 \mathrm{~nm}\left(\mathrm{~K}_{\mathrm{d} 490}\right)$ derived from chlorophyll-a absorption, an output of the GSM01 merging process [Pinnock et al., 2008]. Lastly, an SST analysis at $0.1^{\circ}$ resolution was obtained from Meteo-France. This analysis is an optimal interpolation of satellite SSTs for 00 UTC daily.

\section{Estimating Diurnal Changes in SST}

[8] The diurnal cycle is defined with reference to the foundation temperature. One estimate of foundation temperature is the midnight SST analysis. An alternative is the radiometric temperature observed just before local sunrise ("pre-dawn" SST). The analysis SST and the predawn SST differ by $0.08 \pm 0.31 \mathrm{~K}$ over the domain and period. There are advantages and disadvantages for each estimate. The analysis SST is spatially complete, whereas aerosol or cloud prevent a pre-dawn SST being available; however, pre-dawn SST is retrieved identically to the SSTs obtained later in the day, unlike the analysis SST.

[9] The diurnal component of SST, dSST, is the SEVIRI SST during the day, minus the foundation temperature. Combining the errors in the estimates of the foundation temperature and radiometric SST, the random error in this dSST estimate is $\sqrt{0.31^{2}+0.11^{2}}=0.33 \mathrm{~K}$ when the midnight analysis is used, and $\sqrt{2 \times 0.11^{2}}=0.15 \mathrm{~K}$ if the pre-dawn SST is used.

[10] We do not use cells on a particular day if the SDI exceeds 0.5 for any hour, or if any dSST is more negative than $-1.4 \mathrm{~K}$ (a $4 \sigma$ threshold). Large negative dSST could indicate a spurious foundation SST or unscreened aerosol or cloud. We exclude cells within $0.2^{\circ}$ of land, to avoid diurnal variability related to sheltered coastal locations.
[11] A cell is defined to show a diurnal warm-layer magnitude $T$ for a given hour if the $3 \times 3$-pixel medianfiltered dSST exceeds $T$ for that hour. This ensures the event is spatially coherent, avoiding spurious identification of events from noisy pixels, but means that the spatial resolution of our analysis is limited to $\sim 20 \mathrm{~km}$. The following analyses are based on the daily maximum value of dSST, hereafter referred to as "peak dSST".

\section{Spatial Distribution of Diurnal Warm-Layer Events}

[12] The mean over the study period of the peak dSST (the "mean peak dSST") is shown in Figure 1a, and exceeds $0.4 \mathrm{~K}$ everywhere. The surface wind stress is known to be a major control of diurnal stratification on time-scales of hours to days. Here, we explore whether spatial variations in the wind field are the principal factor explaining the spatial variability in mean peak dSST over the study period. We do this by finding the proportion of variance explained when mean peak dSST is regressed against a time-mean measure of wind and of water attenuation.

[13] We use four measures of wind from the NWP wind field: the mean wind speed, the mean of the reciprocal of the wind speed, and the maximum wind, in each case for the time-window 0900 to $1500 \mathrm{~h}$ UTC of every day; and also the wind at $1400 \mathrm{~h}$ UTC daily. These daily wind measures are then averaged over the study interval. The spatial variation in the mean over the study period of $\mathrm{K}_{\mathrm{d} 490}$ is used to explore the effect of water optical properties.

[14] Each combination of one wind measure and $\mathrm{K}_{\mathrm{d} 490}$ is used in a linear statistical fit of the spatial variation in mean peak dSST. This is done for North Sea/Baltic and Mediterranean sub-regions (see Table 1) since the regimes can be expected to be quite different. The wind-field measures that account for most mean peak dSST spatial variance are those that capture the prevalence of sustained periods of low wind speeds (mean wind and mean reciprocal wind, rather than maximum wind and wind at $14 \mathrm{~h}$ ). For example, the mean reciprocal of the wind strength (Figure 1b), displays correlation with the mean peak dSST (Figure 1a). This is most clear in the Mediterranean Sea, where we see orographic 
Table 1. Percentage of Variance of Spatial Variability of the Mean Peak Diurnal Warming Explained by Measures of Mean Wind and Mean Water Optical Property, When Fields of One Measure of Wind and of $\mathrm{K}_{\mathrm{d} 490}$ Are Used as Explanatory Factors in a Linear Analysis ${ }^{\mathrm{a}}$

\begin{tabular}{|c|c|c|}
\hline Measure of Wind & North Sea/Baltic: Wind, $\mathrm{K}_{\mathrm{d} 490}$ & Mediterranean: Wind, $\mathrm{K}_{\mathrm{d} 490}$ \\
\hline Mean of reciprocal of wind speed & $4 \%, 18 \%$ & $48 \%, 0 \%$ \\
\hline Mean wind speed & $10 \%, 15 \%$ & $51 \%, 6 \%$ \\
\hline Maximum wind speed & $4 \%, 20 \%$ & $33 \%, 1 \%$ \\
\hline Wind speed at $1400 \mathrm{~h} \mathrm{UTC}$ & $0 \%, 20 \%$ & $28 \%, 0 \%$ \\
\hline
\end{tabular}

${ }^{a}$ Within the overall domain, the North Sea/Baltic area covers ocean pixels north of continental Europe and east of $3{ }^{\circ} \mathrm{W}$, and the Mediterranean area is south of continental Europe and east of $1^{\circ} \mathrm{W}$.

influences on the wind field reflected in the upper ocean diurnal response. For example, the seas to the east of Corsica and Sardinia have high mean peak dSST, with less diurnal warming occurring to the east of the passage between the two islands. The wind field to the east of the passage shows a local maximum (minimum in the reciprocal), reflecting the blocking of westerly winds by the uplands of the islands and the channelling of the surface flow between them.

[15] $\mathrm{K}_{\mathrm{d} 490}$ variability is low in the Mediterranean, but is influential in the North Sea/Baltic sub-region, where it explains up to $20 \%$ of the mean peak dSST spatial variance. The sign is such that high $\mathrm{K}_{\mathrm{d} 490}$ promotes diurnal warming, as one would expect due to increased solar absorption in the surface layer, and hence elevated attenuation is a factor in the diurnal warming events in the coastal areas to the south of the North Sea (Figure 1c). Conversely, the time-mean wind field measures for the North Sea/Baltic areas have little spatial variability, and do not account for significant variability in mean peak dSST.

\section{Frequency and Scales}

[16] We now characterize the frequency and scales of diurnal warm-layer events in the study domain. Figure 2a shows the fraction of days on which a peak dSST exceeding $T$ was observed as a function of $T$. Extreme (which we define as $>4 \mathrm{~K}$ ) events are routinely observed, occurring somewhere within the domain on about half of days. The mean probability that a given point will undergo a $>4 \mathrm{~K}$ cycle on a given day is $\sim 0.003$ (Figure $2 b$ ). The largest peak dSSTs exceed $6 \mathrm{~K}$, affect $0.01 \%$ of the surface, and are seen in the Mediterranean, North and Irish Seas.

[17] Larger peak dSSTs tend to cover smaller areas. For each day, we count the separate areas within which peak dSST exceeds $T$ and aggregate the total area for which peak $\mathrm{dSST}>T$. We sum the count of events and their aggregated area over all days, and find the mean area for events exceeding $T$ as $\frac{\text { total area }}{\text { number of areas }}$. The square root of the mean area is the length scale shown in Figure 2c. The $\sim 4 \mathrm{~K}$ events are associated with length scales of $\sim 40 \mathrm{~km}$, which is twice the finest scale of the present analysis (given our definition of "event" discussed above). Events $>6 \mathrm{~K}$ are at the scale of the analysis, so the amplitude-scale relationship at that extreme may not be valid, and will need further investigation with finer resolution satellite imagery.

[18] Since the wind field is the primary factor explaining the peak dSST, we compare the frequency and scales of diurnal maxima with those of the NWP wind minima, using distributions over the study domain and period of peak dSST and daily measures of wind speed. Areas of sustained low wind are relatively rarer than instantaneously low winds (Figure 2b). There is no day in the study period where wind
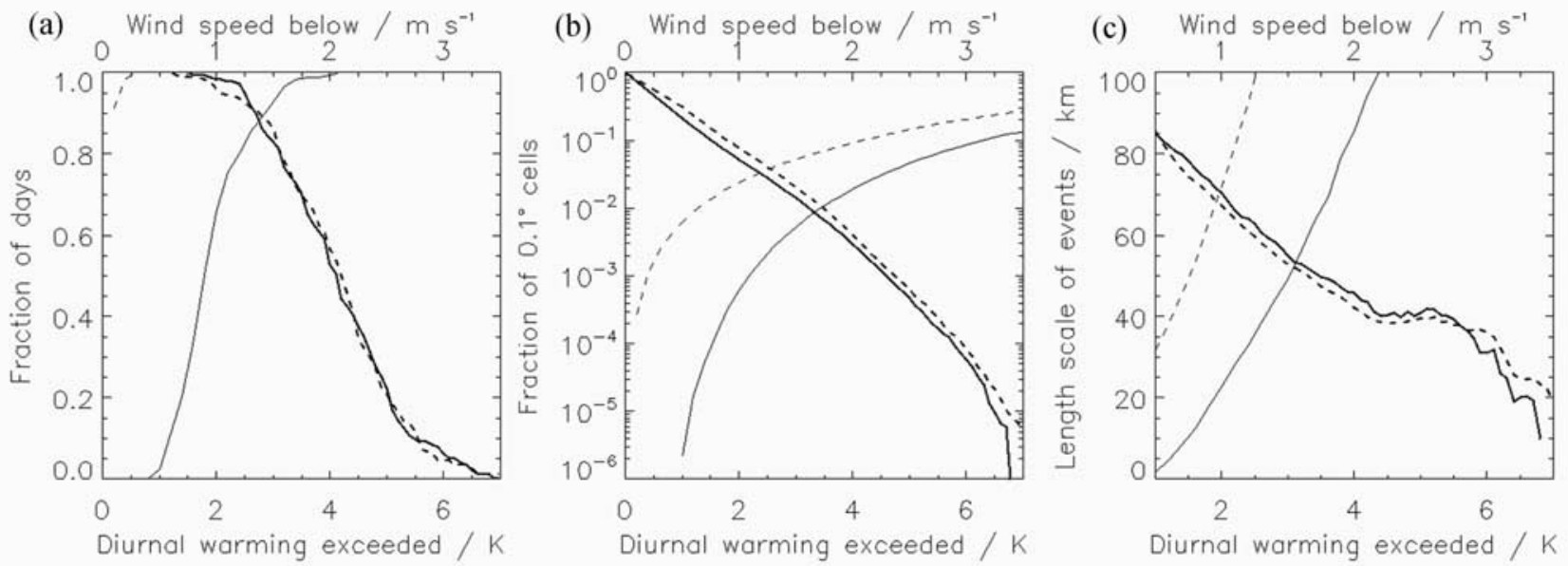

Figure 2. Frequency and scale of ocean diurnal warming events and wind speed minima. Thick solid lines, diurnal warming events (peak dSST) estimated with respect to the midnight analysis SST. Thick dashed lines, peak dSST using predawn SST. Thin solid lines, maximum wind between 0900 and $1500 \mathrm{~h}$ UTC. Thin dashed lines, the wind at $1400 \mathrm{~h}$ UTC. (a) Fraction of days on which a dSST exceeds a given magnitude, and on which a wind minimum is below a given wind speed. (b) Time-average fraction of $0.1^{\circ}$ latitude-longitude cells (ocean only) in which a dSST exceeds a given magnitude, and in which a wind minimum is below a given wind speed. (c) Length-scales as a function of dSST and wind speed. 
less than $0.4 \mathrm{~m} \mathrm{~s}^{-1}$ is sustained between 0900 and $1500 \mathrm{~h}$ at any location. Winds are sustained below $1 \mathrm{~m} \mathrm{~s}^{-1}$ between 0900 and $1500 \mathrm{~h}$ for at least one location on a majority (65\%) of days, however.

[19] In the previous section, the $1400 \mathrm{~h}$ UTC wind field explained less of the spatial variation in mean peak diurnal warming than measures that capture sustained low wind conditions. Figure 2 verifies this. On average, the probability of a wind speed at $1400 \mathrm{~h}$ of $0.2 \mathrm{~m} \mathrm{~s}^{-1}$ or less is $3 \times 10^{-4}$ (Figure 2b). Such minima at $1400 \mathrm{~h}$ therefore occur too frequently to explain peak dSSTs exceeding about $5 \mathrm{~K}$, for which the chances are $<3 \times 10^{-4}$. Sustained wind minima are rare enough, however, to be an explanatory factor for the full range of diurnal warming events. This makes sense: we would not expect as much peak diurnal warming on a day when the morning was windy and then dropped, as on a day of sustained low winds. This dynamic behaviour is also displayed in physical models of diurnal warming. Parameterisations of diurnal warming based on regression to instantaneous wind [e.g., Gentemann et al., 2003; M. J. Filipiak et al., manuscript in preparation, 2008] cannot capture the upper range of dSST for this reason, although they are useful to estimate the expected dSST when satellite winds and SSTs are simultaneously available.

[20] The length scales of areas of sustained low winds are smaller than those of instantaneously low winds (Figure 2c). The reason is that wind minima may move by distances comparable to their length scales in the course of a few hours.

\section{Conclusion}

[21] Small scale $(\sim 40 \mathrm{~km})$ extreme diurnal warming events (peak $>4 \mathrm{~K}$ ) are routinely observable in SEVIRI SSTs in the Mediterranean and European shelf seas. Many cases of peak amplitudes of dSST $>6 \mathrm{~K}$ have been observed with an estimated error of a third of a degree kelvin, using time-resolved (hourly) observations that track the daily cycle. The spatial variability in mean peak diurnal warming is dominated by the prevalence of low wind speeds in the western Mediterranean Sea, with evident orographic influences. In the North and Baltic Seas, the influence of the optical attenuation coefficient of water is important, and promotes diurnal warming in high-opacity coastal waters. We have characterized the frequency and spatial scales of peak diurnal warming and wind minima. Extreme diurnal warming events have shorter length scales than equally prevalent instantaneous wind speed minima. This reflects the fact that sustained low winds are required for extreme warming events to be observed.

\section{References}

Donlon, C., et al. (2007), The global ocean data assimilation experiment high resolution sea surface temperature pilot project, Bull. Am. Meteorol. Soc., 88(8), 1197-1213, doi:10.1175/BAMS-88-8-1197.

Fairall, C. W., E. F. Bradley, D. P. Rogers, J. B. Edson, and G. S. Young (1996), Bulk parameterization of air-sea fluxes for tropical ocean global atmosphere coupled ocean atmosphere response experiment, J. Geophys. Res., 101, 3747-3764.

Flament, P., J. Firing, M. Sawyer, and C. Trefois (1994), Amplitude and horizontal structure of a large diurnal sea surface warming event during the coastal ocean dynamics experiment, J. Phys. Oceanogr., 24(1), $124-139$.

Gentemann, C. L., C. J. Donlon, A. Stuart-Menteth, and F. J. Wentz (2003), Diurnal signals in satellite sea surface temperature measurements, Geophys. Res. Lett., 30(3), 1140, doi:10.1029/2002GL016291.

Kawai, Y., and A. Wada (2007), Diurnal sea surface temperature variation and its impact on the atmosphere and ocean: A review, J. Oceanogr., 63, $721-744$.

Kennedy, J. J., P. Brohan, and S. F. B. Tett (2007), A global climatology of the diurnal variations in sea-surface temperature and implications for MSU temperature trends, Geophys. Res. Lett., 34, L05712, doi:10.1029/ 2006GL028920

Le Borgne, P., G. Legendre, and A. Marsouin (2006), Operational SST retrieval from MSG/SEVIRI data, paper presented at the 2006 EUMETSAT Conference, Helsinki, Finland, 12-16 June.

McNeil, C. L., and L. Merlivat (1996), The warm oceanic surface layer: Implications for $\mathrm{CO}_{2}$ fluxes and surface gas measurements, Geophys. Res. Lett., 23, 3575-3578.

Merchant, C. J., O. Embury, P. Le Borgne, and B. Bellec (2006), Saharan dust in night-time thermal imagery: Detection and reduction of related biases in retrieved sea surface temperature, Remote Sens. Environ., 104, 15-30.

Murray, M. J., M. R. Allen, C. J. Merchant, A. R. Harris, and C. J. Donlon (2000), Direct observations of Skin-Bulk SST variability, Geophys. Res. Lett., 27, 1171-1174.

Pailleux, J., J-F. Geleyn, and M. Tardy (2005), Les progrès récents de la prévision numérique à Météo-France, Météorologie, 8ème Sér., 48, 2-5.

Pinnock, S., O. Fanton d' Anton, and S. Lavender (2008), GlobColour: A precursor to the GMES Marine Core Service Ocean Colour Thematic Assembly Centre, ESA Bull., 132, 43-49.

Ramp, S. R., R. W. Garwood, C. O. Davis, and R. L. Snow (1991), Surface heating and patchiness in the coastal ocean off central California during a wind relaxation event, J. Geophys. Res., 96, 14,947-14,957.

Stramma, L., P. Cornillon, R. A. Weller, J. F. Price, and M. G. Briscoe (1986), Large diurnal sea-surface temperature variability: Satellite and insitu measurements, J. Phys. Oceanogr., 16, 827-837.

Stuart-Menteth, A. C., I. S. Robinson, and P. G. Challenor (2003), A global study of diurnal warming using satellite-derived sea surface temperature, J. Geophys. Res., 108(C5), 3155, doi:10.1029/2002JC001534.

Ward, B. (2006), Near-surface ocean temperature, J. Geophys. Res., 111, C02004, doi:10.1029/2004JC002689.

Webster, P. J., C. A. Clayson, and J. A. Curry (1996), Clouds, radiation, and the diurnal cycle of sea surface temperature in the Tropical Western Pacific, J. Clim., 9, 1712-1730.

E. Autret and J.-F. Piollé, Ifremer, B.P. 70, F-29280 Plouzané, France. M. J. Filipiak and C. J. Merchant, School of GeoSciences, University of Edinburgh, Crew Building, King's Buildings, Edinburgh EH9 3JN, UK. (c.merchant@ed.ac.uk)

S. Lavender, School of Earth, Ocean and Environmental Sciences, University of Plymouth, Plymouth PL4 8AA, UK.

P. Le Borgne and H. Roquet, Centre de Météorologie Spatiale, MétéoFrance, B.P. 147, F-22302 Lannion Cedex, France. 